l:as widened her studies, and must, I should think, recognise with pride the stalwart growth of her early friend. May they be 'rawn nearer together, and feel the warm glow which is 1.rcluced by the sympathy of a common love for truth.

\section{THE INTERNATIONAL GEOLOGICAL CONGRESS AT ZURICH.}

THE sixth meeting of the International Geolozical Congress was held at Ziirich from Wednesday, August 29, to Monlay, September 3, and was highly representative. Óver 220 members were present, including leading geologists from all parts of Europe. Swiss and German members were in the inajority. IVe may mention the names of MM. Renevier, Heim, Golliez, Forel, Schardt among the Swiss representatives, and liaron Richthofen, MM. Beyrich, Hauchecorne, Zittel, Credner, Groth, Gïmbel among the German. From Austria there were present, among others, MM. Suess, Mojsisovics, Tietze, Penck; from France, Prince Roland Bonaparte, MII. Gaudry, de Lapparent, Michel Levy, Bertrand, de Margérie; from Britain, Sir A. Geikie, Sir J. Lubbock, Prof. Hughes, Prof. Sollas, Mr. IV. Topley; from Scandinavia, Prof. Brögger ; from Belgium, Prof. Dewalque ; from Italy, Prof. Capellini, MM. Pellati, de Gregorio ; from Russia, MMI. Karpinsky, Nikitin, Pavlov, von Toll; from Roumania, M. Stefanescu; from the United States, Profs. R. Pompelly, Lester IVard, van Hise. Prof. Haeckel, of Jena, was also present at several meetings.

Prof. Capellini opened the Congress, and called Prof. Renevier to the presidential chair for the meeting at Zuirich. The new President intimated in his address that, according to a decision of council, the official language of the Congress should remain as before, French; at the same time communica. tions made in German would be accepted, and would be reported in the same language. Communications written in other languages had to be translated into French.

Vithout doubt the most important feature of the Congress was the new international geological map, which has been under course of preparation in Berin since the Congress meeting of $188 \mathrm{I}$, and is now exhilited for the first time. A report on its progress was read by Dr. Hauchecorne, of Berlin. The topographical groundwork has been prepared by Kilpert, to scale i : 1,500,000; the system of geological colouring followed has been most successful, and the Congress has certainly every reason to be satisfied with the result of the co-operation of the various surveys and societies to produce an international map. The whole map will contain 49 sleets; only six are now ready for issue, including the north.west part of Europe, Northern Germany, with parts of France, Belgium, Poland, Sc. The next part, to be issued within a year, will contain ten sheets, and will include the British Isles, France, Spain and Portugal, Italy, and Switzerland. Some difficulty has arisen in regard to the older Palreozoic rocks of various districts, and also as to the method of showing the Quaternary beds. It is now settled that solid rocks, where their distribution is known, will be shown by thin bands of colour over the general solour for Quaternary beds. (We reserve a fuller notice of this important work until the sheets are published.)

The subscription for the entire map is $£ 4$, but this can be paid in instalments as the various parts are published. The proportion for the first part will be ros. Subscriptions must be sent to Dietrich Reimer, Berlin, before the end of December 1894 ; alter that the subscription price will be raised.

On three days of the Congress meeting, communications were delivered to a general assembly of members; on one day, sections were formed, and a large number of papers in this way read. Unabated interest made itself felt throughout. At the general assembly on August 29, Prof. Suess gave an address "On the Southern and the Northern Alps," in which he distinguished two main directions of movement in the Alps. The Northern zone and the Central chain of the Alps formed a region of "zufluss" (flow towards the North Pole); the Southern zone, continued into the Dinarian Alps, was a region of "abfluss". (flow away from the North Pole). In the former case the relations were in harmony with those of general European movements; in the latter, the relations were associated with those of Asiatic chains.

Prof. Heim described the "Geology of the neighbourhood of Zirich," and made it most clear by reference to a splendid set of

$$
\text { No. I 299, VOL. 50] }
$$

original maps and models. During the course of the Congress Prof. Heim also organised several excursions on the lake and on its banks, demonstrating that post-glacial movements of old fluvial terraces are in direct connection with the origin of the Lake of Zürich. As might have been expected, animated discussions were held among the members on the points at issuethe origin of the lake-basin, proofs of interglacial periods, mountain -movement which had affected glacial deposits, original and ultimate direction of the valleys, \& c.

On August $3 \mathbf{I}$, the general assembly was addressed by $\mathbf{M}$. Michel Levy and Prof. von Zittel. Michel Levy's subject was "The principles to be foilowed in a universal classification of the rocks." He regretted the confusion which threatened petrography with regard to its classification and nomenclature. Every day the number of names derived from particular localities increased, and useless synonyms were added. He proposed that some general system of classification should be agreed upon by petrographers, and suggested it might be founded ( 1 ) on the texture-affording the great divisions ; (2) on the essential constuent minerals, to give the names of the smaller groups. In compliance with M1. Michel Levy's desire, a Congress com. mission was appointed to consider and revise the nomenclature.

Prof. von Zittel spoke on "Phylogeny, Ontogeny, and systematic arrangement." He gave a word of warning against the assumption that Darwin's Theory of Descent had been actually demonstrated by palrontology. In his experience its application to palrentology had been in but few cases successful Great breaks occurred between the various classes of fossil animals for which there was still no sufficient explanation. Again, Ernst Haeckel's law, that the development of one individual repeats the development of the whole family, had been confirmed in few classes of palæontological forms. The tendency of recent research had been becoming more and more subjective; even young investigators freely constructed new species, new genera, a new system of classification or line of descent. Others as freely questioned the validity of the new names and families, until a kind of anarchy prevailed in some of the groups of the plant and animal kingdom. Solid facts and experiences must be carefully studied, while theory, even the most brilliant, must be held at its mere theoretical value.

At the general sitting on Saturday, September I, Sir Archi. bald Geikie and M. Marcel Bertrand spoke. Sir A. Geikie's paper, delivered in French, was on the "Banded Structure of oldest Gneisses and Tertiary Gabbros." Intrusive basic rocks of Tertiary age in which no mechanical deformation had taken place, had assumed a banded structure during their crystallisation from the original magma, the bands being occasionally plicated. The structure exactly resembled what is observed in many old banded gneisses, and arguing from analogy, these gneisses might have acquired their banding during their original consolidation, and not as the result of subsequent dynamometamorphism. A series of photographs admirably illustrated this suggestion.

M. Bertrand treated the "Structure of the French Alps and the recurrence of certain facies." After describing the metamorphi:m of various sedimentary formations into the condition of gneiss as the result of great dynamic changes, he pointed out that in different countries and in quite different formations certain facies followed each other in the same order of succession. These were a deep-sea facies, a "Flysch" facies formed during uprise, followed by an archipelago and river facies. In the French Alps, for example, the deep-sea facies was represented by the Devonian gneiss, the period of movement by the carboniferous deposits, the shallow water by the later red sand. stones. Taking the Swiss Alps, the same facies recurred in younger formations; one might distinguish goeiss of Permian age, Flysch-(I) fine and schistose of 'Triassic and Jurassic age : (2) the coarser deposits of Cretaceous and Focene age-and ulimately the archipelago facies of molasse and nagelflue in young Tertiary and Glacial time.

M. de Margérie read the report of the Commission of Bibliography. In accordance with the council, the Commission offers to furnish gratuitously a copy of the Catalogue of Geo. logical Bibliographies, at present in the press, not only to all the members of the preceding Congress, as had been agreed upon at Washington, but also to those of the Congress of Zürich. The sectional meetings on Thursday, August 30 , were of a special character. At the General Geology Section, with Prof, de Lapparent as president, most of the papers related to glacial questions. The Congress, acting upon proposals of 
Prof. F. A. Forel and Captain Marshall Hall, has appointed a committee to investigate the variations of glaciers. Represen. tatives of various countries are appointed. Prof. Forel and Dr. L. du Pasquier will have charge of this committee, the expenses of which will be defrayed by Prince Roland Bonaparte, the representative of France on the committee.

Dr. A. Rothpletz spoke on "Overthrusts and their methodical investigation"; MI. Steinmann gave a note on the "Extent of the Indo.Pacific Cretaceous region." The Section of Stratigraphy and Palæontology, presided over by M. Gaudry, heard papers by Prof. Hull, by MII. Sacco, Fallot, MayerEymar, Depéret; on "Tertiary strata and their classifica tion," by Profs. Steinmann and Boehm, and by M. Pavlov on "Cretaceous strata"; by M. Kilian, on "the limit of the Jurassic and Cretaceous systems" ; and by M. Stephanescu, on the "Fossil camel in Roumania." The other sections were Mineralogy and Petrography, M. Michel Levy presiding; and Applied Geology, Dr. Hauchecorne presiding. At the Mineralogy and Petrography Section several papers were read; among others, one on the petrography of Attica, by Prof. Lepsius, on grorudites and tingnaites, by Prof. Brögger. Prof. Groth showed a simple apparatus for demonstrating the direcvion of the vibrations in biaxial crystals.

An interesting interlude was formed at the meeting on August $3 \mathrm{I}$, by the presentation to Geheimrath Beyrich of a magnificent wreath of Alpine flowers made in the name of the assembled geologists. The day was the eightieth anniversary of Beyrich's birth, and Prof. Heim expressed the feeling; of all present in the warm words of congratulation and appreciation which he addressed to the veteran geologist. Not less touch. ing was the reply of the Geheimrath to the graceful token of love and respect from his colleagues of all European nations.

Space will not permit a description of the excellent exhibition of maps, photographs, models, and specimens in connection with the Congress. Exhibits had been sent from all countries. Also the great collection of the Zuirich museums was an attraction in itself, and Prof. Heim was untiring in his efforts that all the guests should see all and even more than all which they had hoped to observe. The new geological map of Switzerland, scale I : 500,000 , prepared by Heim and Schmidt, won the admiration of all, and together with the geological guide-book of the excursions published by the organisation committee, will remain as a valuable, lasting witness of the enterprise and energy displayed by Switzerland and her professors on the occasion of the sixth Congress.

It is rather unfortunate that the weather, which had been the best of summer weather during the excursions in the Jura Mountains previous to the meeting, and throughout the meeting itself, should have broken just as the excursions into the Alps began. Rain and mist undoubtedly bid fair to mar the enjoyment and lessen the benefits. From September 17 to 23 an excursion will be conducted by Profs. Penck, Brückner, and du Pasquier, for the study of glacial appearances in the Alps. A special paper has been published uy these three geologists, more especially with a view to this excursion, but also of general interest, entitled "The Glacial System of the Alps."

The seventh meeting of the International Geslogical Congress will be held in 1897 at St. Petersburg. 'The geological tours proposed were shown in a map of Russia exhibited during the Congress. An excursion across Russia and the Ural MIountains will precede the St. Pelersburg meeting, and one is arranged to be undertaken to the Caucasus and the Caspian Sea at the close of the meeting. 'The Czar, it is said, has invited the Congress to St. Petersburg, and has already subscribed 30,000 roubles to defray in part the expenses of the Congress.

\section{THE INTERNATIONAL CONGRESS OF HYGIENE.}

THE International Congress of Hygiene and Demography, recently held at Budapest, does not appear to have been very successful from a scientific point of view. The medical journals say that serious work was impossible at the Congress, owing to the numerous social amusements and entertainments provided for the members. This opinion is borne out in a report in the Times, to which we are indebted for the following notice.

Our contemporary remarks that unless some sweeping reforms are introduced into the procedure of the Congress

$$
\text { No. I 299, vOL. 50] }
$$

the same loss of prestige which has reduced other similar institutions to impotence or extinction seems certain to overtake it. The Congress appears to have ended in a chootic confusion for which the word fiasco is none too strong, and the principal reasons for this unforiunate state of things are said to be (I) an overwhelming development of what may be called the picnic element ; (2) an abuse of the system of passing sectional resolutions; (3) the superabundance of papers.

But, in spite of the confusion and turmoil resulting from the foregoing defects of procedure, an abundance of valuable material was brought forward at the Congress, some of which might, under more favourable circumstances, have been foccsied into a shape which would exercise a real influence on practical questions of public health and social economy. Much sound and useful work, for instance, was done upon such question 3 as the housing of the working classes, the influence of dwelling; and occupations upon health, the movements of population, and especially the townward migration, upon the condition of the insane, upon school hygiene, practical sanitation, and many others. The real scientific life of the Congress, however, lay in the department dealing with infectious disease and bacteriology. Here three crowded meeting; took place on three successive days to discuss the following questions:-(I) Immunity from infectious disease ; (2) diphtheria ; (3) cholera.

The first of these is of great practical importance, because the future of medicine, from the present bacteriological point of view, lies in solving the problem of immunity. According to one school immunity is effected by certain cells (leucocytes) which eat up the germs, and are therefore called phagocytes. This fascinating theory was introduced a few years ago by M. Metchnikoff, the eminent cbief of the Pasteur Institute in Paris ; but the balance of opinion seems to be turning against it in favour of the theory that the germs are mainly destrojed by certain chemical substances contained in the watery part of the blood. Prof. Buchner, of Munich, is a prominent supporter of this theory, and his paper, read at the Congress, summarises the latest views on the subject. "The natural capacity for resistance to infection (the so-called natural immunity) rests on essentially different conditions and causes from the artificial or acquired immunity. The former rests on the one side upon the bactericidal activity of a substance called Alexine, which is secreted by the organism, on the other by a natural insusceptibility of the cells and tissues of the body to particular bacterial poisons. The leucocytes play an important part in the natural protection of the organism, not, however, as phagocytes, but through the action of substances secreted by them. Acquired immunity, upon the other hand, rests on the presence of modified bacterial products, the so.called Antitoxine, either in the blood or in the tissues of the body." M. Metchnikoff defended his theory of phagocytosis with great vivacity, but the other leading bacteriologists present, including Prof. Roux, of Paris, were on the other side. The debate marks a step in the advance of knowledge, though not a very decided one.

The morning devoted to diphtheria was the central point of the Congress. An overflowing and animated audience attended the meeting. This fearful disease is the most burning question in the medical world at the present time, partly because of its alarming increase, and more recently because of the hopes entertained of the new method of treatment, derived from bacteriological research. Prof. Löffler, the euninent discoverer of the diphtheria bacillus, opened the proceedings by reading the German report, which recommended "immediate bacteriological examination of all suspected cases; notification to the police of all bacteriologically determined cases and of all doubt. ful ones; isolation of every case; protective inoculation with serum of persons about the invalid, particularly children; extension of this principle as far as possible in families and schools; disinfection, keeping of convalescents apart until the bacillus has disappeared."

Similar drastic measures were recommended in the French report. The English report did not suggest any practical measures for dealing with the evil, but pleaded for more careful study, and more accurate knowledge of its causes and conditions. The Danish, Hungarian, Swedish, and Swiss reports also pleaded for further investigation. It is much to be regretted that the Congress could not find time to formulate some, and carefully-weighed, conclusions on this important matter.

In a debate on chalera, which followed in the same section, Prof. Max Gruber said, at the commencement of his address, that the bacteriology of the disease is by no means so simple 